\title{
Screening Diospyros mespiliformis extract for antimalarial potency
}

\author{
Bulus ADZU ${ }^{1,2 *}$ and Oluwakanyinsola Adeola SALAWU ${ }^{2}$ \\ ${ }^{1}$ Pharmaceutical Chemistry Unit, School of Pharmacy, Kampala International University, \\ Western Campus, Ishaka, P.O. Box 71, Bushenyi, Uganda. \\ ${ }^{2}$ Department of Pharmacology and Toxicology, National Institute for Pharmaceutical \\ Research and Development, PMB 21, Abuja, Nigeria. \\ *Corresponding Author, E-Mail: bulusadzu@yahoo.com Tel.: +256 75 2659615; +2348084848802
}

\begin{abstract}
Diospyros mespiliformis is used in ethnomedical practice for treating malaria attack. The aqueous extract of the plant's stem bark was investigated for in vivo antiplasmodial potency in mice. Curative effect against established infection, suppressive activity against early infection and prophylactic effect in residual infection were tested against Plasmodium berghei berghei infected mice. Result shows that the extract (50-200 $\mathrm{mg} / \mathrm{kg}$, p.o.) has significant $(\mathrm{p}<0.05)$ dose dependent activity against the parasite in the curative and suppressive test, and repository effect at high doses (100 and $200 \mathrm{mg} / \mathrm{kg}$, p.o.). The extract also prolonged the survival time of the infected mice. Phytochemical test revealed the presence of saponins, alkaloids, tannins, steroids and terpenes, and the $\mathrm{LD}_{50}$ was established to be $1095.4 \mathrm{mg} / \mathrm{kg}$, i.p. in mice. The result shows that the extract has antimalarial potency.

(C) 2009 International Formulae Group. All rights reserved.
\end{abstract}

Keywords: Diospyros mespiliformis; Plasmodium berghei berghei; Phytomedicine

\section{INTRODUCTION}

Malaria is caused by the Plasmodium genus of protozoa parasites. It is the most important human parasitic infection (Greenwood et al., 2005) with threats to lives in sub-Saharan Africa (WHO, 2005) and little success achieved to control it (White et al., 2004; Lewison and Srivastava, 2008). Traditionally used antimalarials of plant origin have helped in reducing the problems malaria attack posed (Willcox and Bodeker, 2000). Interestingly, some of the plants used have shown real antiparasitic activity (Hilou et al., 2006) and most of them are relatively safe (Ajaiyeoba et al., 2006; Kaou et al., 2008). Diospyros mespiliformis Hochst (Ebenaceae) is used in ethnomedical practice against malaria in northern Nigeria (Etkin, 1997). Previous studies in our laboratory showed that the plant has analgesic, anti-inflammatory and antipyretic effects (Adzu et al., 2002a), with CNS activity that is sedative in nature (Adzu et al., 2002b). The plant was also reported to have potent antibacterial (Adeniyi et al., 1990; Lajubutu et al., 1995) and anti-trypanasomal activities (Freiburghaus et al., 1996). In this report, we investigated the ethnomedical usage of the plant as an antimalarial (Etkin, 1997) by evaluating the aqueous extract of the plant's stem bark against Plasmodium berghei berghei infected mice. Three experimental models were used: curative effect against established infection; suppressive effect against earlier infection and the repository (prophylactic) potency. The extract's phytochemical constituents and safety level $\left(\mathrm{LD}_{50}\right)$ were also tested. 


\section{MATERIALS AND METHODS}

\section{Plant material}

Diospyros mespiliformis Hochst

(Ebenaceae) ex A.DC--Prodr. (DC.) 8: 672.

1844 [mid Mar 1844] (IK) was collected at Chaza village, Suleja, Niger State, Nigeria in April 2005. It was authenticated by Mal. Ibrahim Muazzam of Taxonomy Unit, Department of Medicinal Plant Research and Traditional Medicine (MPR\&TM), National Institute for Pharmaceutical Research and Development (NIPRD), Abuja, Nigeria. A voucher specimen (NIPRD \#5120) was deposited at the herbarium of the Institute. The stem bark of the plant was carefully removed, cleaned and air dried. The dried material was grounded into powder using pestle and mortar, sieved, and $400 \mathrm{~g}$ of the material macerated in 11 of distilled water with occasional stirring using a mechanical shaker (GFL, Germany) for $24 \mathrm{~h}$. The mixture was then filtered, and freeze-dried using Lyovac GT2 (Germany). It gave a yield of $9.74 \% \mathrm{w} / \mathrm{w}$ of crude starting material.

\section{Phytochemical test}

The extract was tested for its phytochemical constituents such as tannins, saponins, alkaloids, glycosides, flavanoids, steroids, terpenes and anthocyanines using standard procedures (Evans, 2005).

\section{Animals}

Four-week old (Pierrot et al., 2003) Swiss albino mice obtained from Animal Facility Centre (AFC), NIPRD, Abuja, were used for the study. They were housed in standard polypropylene cages with saw dust as beddings under standard conditions, fed on standard pellet feeds, and given water ad libitum. The mice were used in accordance with the ethical norms of 'NIH Guide for the Care and Use of Laboratory Animals; NIH Publication (No 83-23), The National Academic Press, Washington, DC (1985).

\section{Acute toxicity test}

The safety of the extract was assessed by testing for its $\mathrm{LD}_{50}$ using Lorke's (1983) method. Briefly, the extracts were administered at the doses of 10, 100, 1000 and $2000 \mathrm{mg} / \mathrm{kg}$ i.p. to four groups of mice. The mice were then observed for signs and symptoms of toxicity after treatment over a period of $24 \mathrm{~h}$, and deaths within this period were recorded. The $\mathrm{LD}_{50}$ was estimated as the square root of the lowest lethal dose multiplied by the highest non-lethal dose from the second stage of dosing (Vongtau et al., 2004).

Rodent parasite (Plasmodium berghei berghei) and inoculation

Chloroquine sensitive rodent plasmodia: Plasmodium berghei berghei was sourced from National Institute for Medical Research (NIMR), Lagos, Nigeria, by U.A. Katsayal of the Department of Pharmacognosy and Drug Development, Ahmadu Bello University (ABU), Zaria, Nigeria. The parasite was maintained alive in mice at the Department of Parasitology and Entomology, ABU, Zaria by continuous reinfestation (i.p.) (Calvalho et al., 1991) every 4 days. Blood was collected from a donor infected mouse through cardiac puncture and diluted with normal saline. The study mice received $0.2 \mathrm{ml}$ of diluted inoculums i.p. consisting of $10^{7}$ parasitised red blood cell.

\section{Antiplasmodial studies \\ Curative test}

The Rane test (Ryley and Peters, 1970) was used to evaluate the curative potential of the extract against established infection as earlier described (Adzu et al., 2008). Twenty five mice were inoculated as described above, and left untreated until the fourth day $\left(\mathrm{D}_{4}\right)$. The mice were grouped into five $(n=5)$. Groups 1-3 received the extract $(50,100$ and $200 \mathrm{mg} / \mathrm{kg}$, p.o.), Group 4 was treated with chloroquine (CQ) (5 mg/kg, p.o.), while group 5 was left untreated and served as the negative control. Treatment then continued daily to $\mathrm{D}_{7}$ $\left(D_{4}-D_{7}\right)$ when each mouse was tail-bled, and blood smeared unto a microscope slide to make a thin film. The films were fixed with methanol, stained with $4 \%$ Giemsa at $\mathrm{pH} 7.2$ for $45 \mathrm{~min}$ and parasitaemia density determined (Kirby et al., 1993). The survival time of the mice in each group over 30 days was noted (Saidu et al., 2000).

\section{Suppressive test}

This test on early plasmodial infection (Knight and Peters, 1980) was similar to the curative test described above, except that in this test, treatment started immediately after 
the mice were infected with the parasite (Saidu et al., 2000; Okokon and Nwafor, 2009). The mice were then grouped into five $(\mathrm{n}=5)$, and treated with the extract $(50,100$ and $200 \mathrm{mg} / \mathrm{kg}$, p.o.), CQ (5 mg/kg, p.o.) and saline $(10 \mathrm{ml} / \mathrm{kg}$, p.o. $)$ on that first day $\left(D_{1}\right)$. Treatment continued daily for four days. Thin blood film of each mouse was collected on the fifth day $\left(D_{5}\right)$ and examined for blood parasite suppression, by counting the parasitised red blood cells in random field of the microscope slide of both the treated and control groups.

\section{Repository test}

The test was carried out using the residual infection procedure (Peters, 1965). In the test, mice were weighed, grouped into five $(n=5)$ with the mean weight between each group as near as possible, and then treated with the extract $(50,100$ and $200 \mathrm{mg} / \mathrm{kg}$, p.o.), CQ (5 mg/kg, p.o.) and saline ( $10 \mathrm{ml} / \mathrm{kg}$, p.o.), on the first day $\left(D_{1}\right)$. Treatment continued daily for three days $\left(D_{1}-D_{3}\right)$ and mice were all infected with the parasite on the fourth day $\left(D_{4}\right)$. Thin films of blood smears were made from each mouse $72 \mathrm{~h}\left(\mathrm{D}_{7}\right)$ after treatment (Abatan and Makinde, 1986) and mean increase/decrease in parasitaemia in each group determined. The mice were reweighed, and changes between pre and post-treatment body weights were noted.

\section{Data analysis}

Results were expressed as mean \pm SEM. Student's t-test was used to analyse the data between groups and Analysis of Variance (ANOVA) among groups followed by Dunnett's test using GraphPad Prism Version 4.00 for Windows, GraphPad software, San Diego California USA, (www.graphpad.com). $\mathrm{p}<0.05$ was considered significant in all cases.

\section{RESULTS}

Phytochemical tests

The aqueous extract of $D$. mespiliformis gave positive tests for saponins, tannins, steroids, alkaloids and terpenes.

\section{Acute toxicity tests}

The $\mathrm{LD}_{50}$ of the extract was established to be $1095.4 \mathrm{mg} / \mathrm{kg}$, i.p. in mice. Thus, the experimental doses used (50, 100 and 200 $\mathrm{mg} / \mathrm{kg}$, p.o.) were within safe margin.

\section{Curative test}

There was a dose-dependent reduction in the level of parasitaemia in the treated groups unlike in the saline control group in which there was a consistent increase in the blood parasite density. The mean survival time also increased dose-dependently. Death was observed in the control group on day 7 , and by day 10 , all mice in the group died (mean survival time of 8 days). On the other hand, mice in the group that received 200 $\mathrm{mg} / \mathrm{kg}$ survived beyond 21 days. CQ treated group survived the 30 days duration of observation (Table 1).

\section{Suppressive test}

The extract exhibited dose dependent suppression of 32.3-73.2\% (Table 2).

\section{Repository test}

Parasites were detected a day after inoculation in the control group. Mice that received 100 and $200 \mathrm{mg} / \mathrm{kg}$ of the extract, and the CQ group showed significant inhibition of the parasite density and gained weight when compared with their pretreatment data. There was a loss in body weight and inactivity against the parasite in the control and treated groups that received 50 $\mathrm{mg} / \mathrm{kg}$ of the extract (Table 3 ).

Table 1: Curative effect of $D$. mespiliformis in $P$. bergei infected mice.

\begin{tabular}{lcccc}
\hline Treatment & $\begin{array}{c}\text { Dose (mg/kg, } \\
\text { p.o.) }\end{array}$ & \multicolumn{2}{c}{ Mean parasitaemia density } & Survival time \\
Pre- $\left(\mathbf{D}_{3}\right)$ & Post- $\left(\mathbf{D}_{7}\right)$-treatment & (Days) \\
\hline Control & - & $33.4 \pm 3$ & $41.6 \pm 3$ & $8.4 \pm 1$ \\
Extract & 50 & $28.8 \pm 2$ & $13.2 \pm 2^{*}$ & $11.2 \pm 1$ \\
& 100 & $30.4 \pm 3$ & $10.4 \pm 1^{*}$ & $15.2 \pm 1$ \\
& 200 & $31.4 \pm 4$ & $9.6 \pm 1^{*}$ & $22.2 \pm 2$ \\
CQ & 5 & $29.2 \pm 1$ & $2.2 \pm 1 *$ & 30 \\
\hline D3 = Day three; D7 $=$ Day seven; CQ $=$ chloroquine; *Significantly different: F $[(4,24)=4.67 ; \mathrm{p}<0.05]$
\end{tabular}


Table 2: Suppressive activity of $D$. mespiliformis in $P$. bergei-infected mice.

\begin{tabular}{lccc}
\hline Treatment & $\begin{array}{c}\text { Dose } \\
\text { (mg/kg, p.o.) }\end{array}$ & $\begin{array}{c}\text { Mean parasitaemia density } \\
\mathbf{D}_{\mathbf{5}}\end{array}$ & \% Inhibition \\
\hline Control & - & $32.8 \pm 3$ & - \\
Extract & 50 & $22.2 \pm 2$ & $32.3^{*}$ \\
& 100 & $18.4 \pm 2$ & $43.9^{*}$ \\
& 200 & $8.8 \pm 1$ & $73.2^{*}$ \\
$\mathrm{CQ}$ & 5 & $2.6 \pm 1$ & $91.5^{*}$ \\
\hline \multicolumn{2}{c}{ D5 = Day five; CQ = chloroquine;* indicates significantly different: $\mathrm{F}[(4,24)=5.0 ; \mathrm{p}<0.05]}$.
\end{tabular}

Table 3: Prophylactic activity of $D$. Mespiliformis in P. bergei-infected mice.

\begin{tabular}{lcccc}
\hline Treatment & $\begin{array}{c}\text { Dose } \\
(\mathbf{m g} / \mathbf{k g}, \mathbf{p . o} .)\end{array}$ & $\begin{array}{c}\text { Mean parasitaemia density } \\
\mathbf{D}_{\mathbf{1}}\end{array}$ & $\begin{array}{c}\text { Body Weights }(\mathbf{g}) \\
\mathbf{D}_{\mathbf{1}}\end{array}$ & $\mathbf{D}_{\mathbf{7}}$ \\
\hline Control & - & $28.4 \pm 3$ & $21.94 \pm 1$ & $18.8 \pm 1^{*}$ \\
Extract & 50 & $22.8 \pm 4$ & $22.04 \pm 1$ & $19.42 \pm 2^{*}$ \\
& 100 & $16.6 \pm 3^{*}$ & $21.92 \pm 1$ & $22.12 \pm 1$ \\
& 200 & $8.2 \pm 2^{*}$ & $22.12 \pm 2$ & $22.86 \pm 1$ \\
CQ & 5 & $3.2 \pm 1^{*}$ & $22.18 \pm 1$ & $24.2 \pm 2$ \\
\hline D1 = Day one; D7 = Day seven; CQ = chloroquine; *Significantly different: $\mathrm{F}[(4,24)=4.45 ; \mathrm{p}<0.05]$.
\end{tabular}

\section{DISCUSSION}

The results showed that the aqueous extract of $D$. mespiliformis exhibited significant $(\mathrm{p}<0.05)$ curative effect against established infection and suppressive potency against early infection of the parasite. It also has prophylactic action at high doses (100 and $200 \mathrm{mg} / \mathrm{kg}$ ). P. berghei has been used in studying the activity of potential antimalarials in vivo in rodents (Thomas et al., 1998; Pedroni et al., 2006) and it produces diseases similar to those of human plasmodial infection (English et al., 1996; Kumar et al., 2006). Agents that suppress the parasite (antiplasmodial effect) were known for antimalarial activity (Calvalho et al., 1991; Elufioye and Agbedahunsi, 2004). The mechanism of this antiplasmodial action of the extract at this stage is not clear, however there is that possibility that the agent might have acted through metabolic activation of the immune system (Waako et al., 2005), which can be attributed to the useful phytochemicals in the plant. Plant components like terpenes and alkaloids (detected in the extract), as well as xanthones and flavonoids, were reported to have antiplasmodial effect (Phillipson and Wright, 1990; Christensen and Kharazmi,
2001; Go, 2003). D. mespiliformis is used in areas where malaria is endemic, where individuals might possess at least some degree of immunity in which relief may in addition be symptomatic. Our earlier studies on extracts of D. mespiliformis showed that it has analgesic, anti-inflammatory, antipyretic and sedative properties (Adzu et al., 2002a, 2002b). Agents with such properties are known to produce additional remedy to malaria patients (Addae-Kyereme et al., 2001). It is plausible that the antiplasmodial activity of the extract might be enhanced by its further purification. Work is presently on going in our laboratories to isolate and characterize the active antiplasmodial component of the plant

\section{ACKNOWLEDGEMENTS}

The authors thank Ibrahim Muazzam for the plant material and its authentication, Umar Adam Katsayal for the rodent parasite and Elisha Baba for the Parasitaemia counts. B. Adzu was a member of Nigerian Technical Aid Corps (TAC: 2006-2008 biennial service) volunteer scheme, posted to Kampala International University, Western Campus, Ishaka, Uganda. 


\section{REFERENCES}

Abatan MO, Makinde MJ. 1986. Screening Azadirachta indica and Pisum sativum for possible antimalarial activities. $J$. Ethnopharmacol., 17: 85 -93.

Addae-Kyereme J, Croft SL, Kendrick H, Wright CW. 2001. Antiplasmodial activities of some Ghanaian plants traditionally used for fever/malaria treatment and of some alkaloids isolated from Pleiocarpa mutica in vivo antimalarial activity of pleiocarpine. $J$. Ethnopharmacol., 76: 99-103.

Adeniyi BA, Odelola HA, Oso BA. 1990. Anti-microbial potentials of Diospyros mespiliformis (Ebenaceae). African $J$. Medical Sci., 25: 221 - 224.

Adzu B, Amos S, Dzarma S, Muazzam I, Gamaniel KS. 2002. Pharmacological evidence favouring the folkloric use of Diospyros mespiliformis Hochst in the relief of pain and fever. $J$. Ethnopharmacol., 82: 191-195.

Adzu B, Amos S, Muazzam I, Inyang US, Gamaniel KS. 2002. Neuropharmacological screening of Diospyros mespiliformis in mice. J. Ethnopharmacol., 83: 139-143.

Adzu B, Adamu M, Zakariya ST, Auta IK, Katsayal UA. 2008. Assessing the potency of Pedilanthus tithymaloides latex against Plasmodium berghei berghei infected mice. Int. J. Biol. Chem. Sci., 2: 216-219.

Ajaiyeoba EO, Abiodun OO, Falade MO, Ogbole NO, Ashidi JS, Happi CT, Akinboye DO. 2006. In vitro cytotoxicity studies of 20 plants used in Nigerian antimalarial ethnomedicine. Phytomedicine, 13: 295-298.

Calvalho LH, Brandao MGL, Santos-Filho D, Lopes JLC, Krettli AU. 1991. Antimalarial activity of crude extracts from Brazilian plants studied in vivo in Plasmodium berghei-infected mice and in vitro against Plasmodium falciparum in culture in culture. Brazilian J. Med. Biol. Res., 24:1113-1123.

Christensen SB, Kharazmi A. 2001. Antimalarial natural products: isolation characterization and biological properties. In Bioactive Compounds from Natural Sources: Isolation, Characterisation and
Biological Properties, Tringali C (ed). Taylor \& Francis: London; 379-432.

Elufioye TO, Agbedahunsi JM. 2004. Antimalarial activities of Tithonia diversifolia (Asteraceae) and Crossopteryx febrifuga (Rubiaceae) on mice in vivo. J. Ethnopharmacol., 93: 167-171.

English MC, Waruiri C, Lightower C, Murphy SA, Kirigha G, Marsh K. 1996. Hyponatraemia and dehydration in severe malaria. Archives Dis. Childhood, 74: 201-205.

Etkin NL. 1997. Antimalarial plants used by Hausa in northern Nigeria. Tropical Doctor, 27: 12-16.

Evans WC. (Ed.). 2005. Trease and Evans Pharmacognosy (15th edn). Reed Elsevier India (Pvt) Ltd: New Delhi; 174, 224-304, 411-413, 535.

Freiburghaus F, Kaminsky R, Nkunya MHH, Brun R. 1996. Evaluation of african medicinal plants for their in vitro trypanocidal activity. J. Ethnopharmacol., 55: 1-11.

Go ML. 2003. Novel antiplasmodial agents. Medicinal Plants Reviews, 23: 456-487.

Greenwood BM, Bojang K, Whitty CJM, Targett GAT. 2005. Malaria. The Lancet, 365: 1487-1898.

Hilou A, Nacoulma OG, Guiguemde TR. 2006. In vivo antimalarial activities of extracts from Amaranthus spinosus L and Boerhaavia erecta L. in mice. $J$. Ethnopharmacol., 103: 236-240.

Kaou AM, Mahiou-Leddet V, Hutter S, Aïnouddine S, Hassani S, Yahaya I, Azas N, Ollivier E. 2008. Antimalarial activity of crude extracts from nine african medicinal plants J. Ethnopharmacol., 116: $74-83$.

Knight DJ, Peters W. 1980. The antimalarial action of N-benzyloxydihydrotriazines. The action of clociquanil (BRL50216) against malaria and studies on its mode of action. Annals Trop. Med. Parasitol., 74: $393-404$.

Kumar KA, Singn S, Babu PP. 2006. Studies on the glycoprotein modification in erythrocyte membrane during experimental celebral malaria. Exp. Parasitol., 114: 173 - 179.

Lajubutu BA, Pinney RJ, Roberts MF, Odelola HA, Oso BA. 1995. Antibacterial activity of diosquinone and 
plumbagin from the root of Diospyros mespiliformis (Hostch) (Ebenaceae). Phytother. Res., 9: 346-350.

Lorke D. 1983. A new approach for acute toxicity testing. Archives Toxicol., 54: 275-287.

Lewison G, Srivastava D. 2008. Malaria research, $1980-2004$, and the burden of disease. Acta Tropica, 106: 96-103.

Okokon JE, Nwafor PA. 2009. Antiplasmodial activity of root extract and fractions of Croton zambesicus. J. Ethnopharmacol., 121: 74-78.

Pedroni HC, Bettoni CC, Spalding SM, Costa TD. 2006. Plasmodium berghei: Development of an irreversible experimental malaria model in wistar rats Exp. Parasitol., 113: 193-196.

Peters W. 1965. Drug resistance in Plasmodium berghei Vincka and Lips 1948: I Chloroquine resistance. Exp. Parasitol., 17: 80-89.

Phillipson JD, Wright CW. 1990. Antiprotozoal compounds from plant sources. Planta Medica., 57: 276284.

Pierrot C, Adam E, Lafitte S, Godin C, Dive D, Capron M, Khalife J. 2003. Agerelated susceptibility and resistance to Plasmodium berghei in mice and rats. Exp. Parasitol., 104: 81-85.

Ryley JF, Peters W. 1970. The antimalarial activity of some quinoline esters. Annals Trop. Med. Parasitol., 64: 209-222.
Saidu K, Onah J, Orisadipe A, Olusola A, Wambebe C, Gamaniel K. 2000. Antiplasmodial analgesic and antiinflammatory activities of the aqueous extract of the stem bark of Erythrina senegalensis. J. Ethnopharmacol., 71: 275-280.

Thomas AM, Van Der Wel AM, Thomas AW, Janse CJ, Waters AP. 1998. Transfection systems for animal models of malaria. Parasitol. Today, 14: 248-249

Vongtau HO, Abbah J, Mosugu O, Chindo BA, Ngazal IE, Salawu AO, Kwanashie HO, Gamaniel KS. 2004. Antinociceptive profile of the methanolic extract of Neorautanania mitis root in rats and mice. J. Ethnopharmacol., 92: 317 - 324.

Waako PJ, Gumede B, Smith P, Folb PI. 2005. The in vitro and in vivo antimalarial activity of Cardiospermum halicacabum L. and Momordica foelida Schumch. Et Thonn. J. Ethnopharmacol., 99: 137-143.

White N, Nosten F, Bjorman A, Marsh K, Snow RW. 2004. WHO, the Global Fund and medical practice in malaria treatment. The Lancet, 363: 1160.

WHO. 2005. World Malaria Report 2005. World Health Organisation, Geneva WHO/HTM/MAL/2005 1102.

Willcox ML, Bodeker G. 2004. Traditional herbal medicines for malaria. Brit. Med. J., 329: 1156-1159. 